\title{
DEPOSITO MUDHARABAH, NPF, DAN TINGKAT BAGI HASIL TERHADAP PEMBIAYAAN BAGI HASIL PADA BUS DAN UUS DI INDONESIA TAHUN 2011-20161
}

\author{
Inan Nati Ismah \\ Mahasiswa Program Studi S1 Ekonomi Islam-Fakultas Ekonomi dan Bisnis-Universitas Airlangga \\ Email : inan.nati-12@feb.unair.ac.id \\ Atina Shofawati \\ Departemen Ekonomi Syariah-Fakultas Ekonomi dan Bisnis-Universitas Airlangga \\ Email : atina-o@feb.unair.ac.id
}

\begin{abstract}
:
The aim of the study was to determine the influence Mudharabah Deposit, Non Performing Financing and Profit Sharing Level to Financing Based on Profit Sharing by Islamic Banks and Sharia Business Unit. This study used quantitative research, with purposive sampling. The data used for this study are secondary data gathered from Sharia Indonesia Banking Statistic on Financial Services Authority Website which is monthly report started from January 2011 till August 2016. Dependent variable in the study is financing based on profit sharing (Musyarakah and Mudharabah), then independent variable are Mudharabah Deposit, Non Performing Financing, and Profit Sharing Level. This reserach used analysis technical multiple linear regression. The regression result of this study indicate that mudharabah deposit variable, non performing financing and profit sharing level simultaneously have significant influence to financing based on profit sharing. Meanwhile non performing financing partially has significant influence to financing based on profit sharing.
\end{abstract}

\section{Keywords: Financing based on Profit Sharing, Mudharabah Deposit, Non Performing} Financing and Profit Sharing Level.

\section{Pendahuluan}

\section{Latar Belakang}

Di Indonesia perkembangan perbankan syariah dimulai dengan munculnya UU No.7 Tahun 1992 yang saat ini telah diperbaiki dengan UU No.10 Tahun 1998 tentang Perbankan. Keberadaan undang-undang tersebut memberikan peluang bagi perbankan di Indonesia dalam melakukan kegiatan perbankan berdasarkan prinsip syariah dan prinsip bagi hasil.

Keberadaan bank syariah memiliki kontribusi yang positif dalam pertumbuhan perekonomian dan perbankan syariah di Indonesia. Pada krisis moneter tahun 1998 yang terjadi di
Indonesia mengakibatkan banyak bank konvensional jatuh. Bank syariah mampu menunjukkan perkembangan dan kinerja yang cukup signifikan . perkembangan perbankan syariah di Indonesia menjadi tolak ukur keberhasilan eksistensi ekonomi syariah. Bank Muamlat Indonesia sebagai bank syariah pertama yang menjadi pioneer bagi bank syariah lainnya yang telah lebih dulu menerapkan prinsip syariah ditengah bekembangnya bankbank konvensional (Susanti, 2015). Segala aktivitas bank konvensional yang dilakukan berlandaskan pada system bunga, sedangkan pada bank syariah bunga merupakan riba dan hokum dari riba adalah haram. Seperti yang dijelaskan pada Surat Al-Baqarah 275 :

1) Jurnal ini merupakan bagian dari skripsi Inan Nati Ismah, NIM : 041211433054 , yang diuji pada 16 Februari 2017 
Ismah, et al/ Jurnal Ekonomi Syariah Teori dan Terapan Vol. 5 No. 3 Maret 2018: 231-246;

PENGARUH DEPOSITO MUDHARABAH, NPF DAN TINGKAT BAGI HASIL TERHADAP PEMBIAYAAN BAGI HASIL PADA BUS DAN UUS DI INDONESIA TAHUN 2011-2016

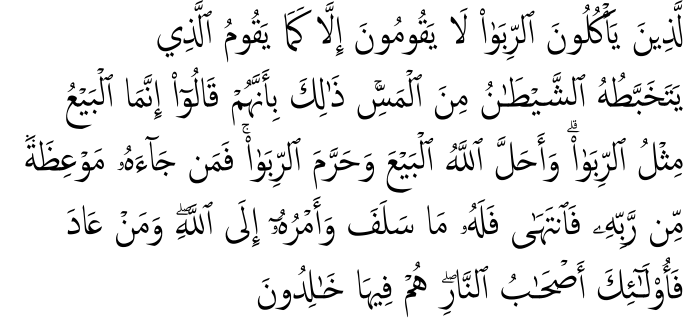

Allażina ya'kulūnar-ribā lā yaqūmūna illā kamā yaqūmullażī yatakhabbatuhusysyaitānu minal- mass, żālika bi'annahum qālū innamal- bai'u miślur-ribā, wa ahallallāhul- bai'a wa harramar- ribā, fa man jā' ahū mau'izatum mir rabbihī fantahā fa lahū mā salaf, wa amruhū ilallāh, wa man 'āda fa ulā'ika as-hābunnār, hum fịhā khālidūn.

Artinya: orang-orang yang makan (mengambil) riba tidak dapat berdiri melainkan seperti berdirinya orang yang kemasukan syaitan lantaran (tekanan) penyakit gila. Keadaan mereka yang demikian itu, adalah disebabkan mereka berkata (berpendapat), Sesungguhnya jual beli itu sama dengan riba, Padahal Allah telah menghalalkan jual beli dan mengharamkan riba. orang-orang yang telah sampai kepadanya larangan dari Tuhannya, lalu terus berhenti (dari mengambil riba), maka baginya apa yang telah diambilnya dahulu (sebelum) datang larangan) dan urusannya (terserah) kepada Allah. orang yang kembali (mengambil riba), maka orang itu adalah penghuni-penghuni neraka, mereka kekal di dalamnya. (Departemen Agama Rl, 2012:47).

Perkembangan perbankan syariah di Indonesia menunjukkan adanya peningkatan. Perkembangan perbankan syariah sampai dengan bulan Agustus 2016 dengan total aset 305.287 miliar rupiah dan jumlah komposisi pembiayaan yang diberikan sebesar 203.318 miliar rupiah. Selama periode Agustus 2016, jumlah Bank Umum Syariah (BUS) dan Unit Usaha Syariah (UUS) tidak mengalami perubahan, namun terjadi penurunan jumlah kantor pada BUS dan kenaikan jumlah kantor pada UUS (Statistik Perbankan Syariah www.ojk.co.id).

Menurut Laporan Statistik Perbankan Syariah bulanan dari periode Januari 2011 sampai dengan Agustus 2016, jumlah pembiayaan yang disalurkan BUS dan UUS yang terdiri dari Mudharabah, Musyarakah, Murabahah, Istishna, ljarah, dan Qardh mengalami peningkatan pada setiap tahunnya. Diantara pembiayaan yang terdiri dari Mudharabah, Musyarakah, Murabahah, Istishna, ljarah, dan Qardh yang memiliki jumlah terbanyak adalah pembiayaan murabahah, kemudian pembiayaan musyarakah dan mudharabah (www.ojk.go.id).

Prinsip dasar dari perbankan syariah adalah prinsip bagi hasil yang sesuai dengan syariah Islam. Produkproduk bank syariah yang berbasis bagi hasil (mudharabah dan musyarakah) seharusnya lebih unggul daripada produkproduk lainnya, namun fenomena yang terjadi adalah pembiayaan dengan akad murabahah masih lebih unggul daripada jumlah pembiayaan bagi hasil (mudharabah dan musyarakah). Tingginya pembiayaan non bagi hasil (murabahah)ini akan menimbulkan 
Ismah, et al/ Jurnal Ekonomi Syariah Teori dan Terapan Vol. 5 No. 3 Maret 2018: 231-246;

PENGARUH DEPOSITO MUDHARABAH, NPF DAN TINGKAT BAGI HASIL TERHADAP PEMBIAYAAN BAGI HASIL PADA BUS DAN UUS DI INDONESIA TAHUN 2011-2016

persepsi public bahwa perbankan syariah

tidak memiliki perbedaan dengan perbankan konvensional. Persepsi ini akan menimbulkan buruknya reputasi perbankan syariah yang dikhawatirkan akan merusak reputasi dan kepercayaan masyarakat tentang bank syariah(Ascarya dan Yumanita:2005).

Terdapat beberapa faktor yang mempengaruhi rendahnya pembiayaan bagi hasil yang pertama adalah dari jumlah dana yang dapat dihimpun oleh BUS dan UUS. Salah satu produk penghimpunan dana yang digunakan dalam penelitian ini adalah deposito mudharabah. Deposito mudharabah yang dapat dihimpun oleh BUS dan UUS pada setiap bulannya tercatat sampai dengan Agustus 2016 sebesar 111.237 miliar rupiah. Faktor yang kedua adalah risiko pembiayaan yaitu pembiayaan bermasalah atau yang disebut juga dengan non performing financing (NPF). Bank Indonesia telah menetapkan besarnya NPF adalah dibawah 5\%. NPF yang dialami oleh BUS dan UUS pada setiap bulannya tercatat sampai dengan Agustus 2016 sebesar 5.55\%. Faktor yang ketiga adalah tingkat bagi hasil yang diperoleh BUS dan UUS dari pembiayaan bagi hasil (mudharabah dan musyarakah).

\section{Rumusan Masalah}

Dari uraian latar belakang di atas dapat dirumuskan permasalahan sebagai berikut:
1. Apakah Deposito Mudharabah, NPF dan tingkat bagi hasil secara simultan berpengaruh signifikan terhadap pembiayaan bagi hasil pada BUS dan UUS di Indonesia tahun 2011-2016?

2. Apakah Deposito Mudharabah secara parsial berpengaruh signifikan terhadap pembiayaan bagi hasil pada BUS dan UUSdi Indonesia tahun 2011-2016?

3. Apakah NPF secara parsial berpengaruh signifikan terhadap pembiayaan bagi hasil pada BUS dan UUSdi Indonesia tahun 2011-2016?

4. Apakah tingkat bagi hasil secara parsial berpengaruh signifikan terhadap pembiayaan berbasis bagi hasil pada BUS dan UUSdi Indonesia tahun 2011-2016?

\section{Tujuan Penelitian}

1. Untuk mengetahui Deposito Mudharabah, NPF dan tingkat bagi hasil secara simultan berpengaruh signifikan terhadap pembiayaan bagi hasil pada BUS dan UUSdi Indonesia tahun 2011-2016.

2. Untuk mengetahui Deposito Mudharabah secara parsial berpengaruh signifikan terhadap pembiayaan bagi hasil pada BUS dan UUSdi Indonesia tahun 2011-2016.

3. Untuk mengetahui NPF secara parsial berpengaruh signifikan terhadap pembiayaan bagi hasil pada BUS dan UUSdi Indonesia tahun 2011-2016.

4. Untuk mengetahui tingkat bagi hasil secara parsial berpengaruh signifikan 
Ismah, et al/ Jurnal Ekonomi Syariah Teori dan Terapan Vol. 5 No. 3 Maret 2018: 231-246;

PENGARUH DEPOSITO MUDHARABAH, NPF DAN TINGKAT BAGI HASIL TERHADAP PEMBIAYAAN

BAGI HASIL PADA BUS DAN UUS DI INDONESIA TAHUN 2011-2016

terhadap pembiayaan bagi hasil

pada BUS dan UUSdi Indonesia tahun 2011-2016.

\section{TINJAUAN PUSTAKA}

Definisi Bank Syariah

Muhammad

(2004

1)

mengatakan bahwa Bank Syariah adalah bank yang beroperasi dengan tidak mengandalkan pada bunga. Bank Islam atau biasa disebut dengan bank tanpa bunga adalah lembaga keuangan/perbankan yang beroperasional dan produknya dikembangkan berlandaskan pada Al Quran dan Hadist Nabi SAW.

Menurut UU No 21 Tahun 2008 Bab I Pasal I ayat 7 tentang bank syariah, disebutkan bahwa Bank Syariah adalah bank yang menjalankan kegiatan usahanya berdasarkan prinsip syariah, serta jenisnya terdiri atas Bank Umum Syariah (BUS) dan Bank Pembiayaan Rakyat Syariah (BPRS). Bank Umum Syariah (BUS) adalah Bank Syariah yang dalam kegiatannya memberikan jasa dalam lalu lintas pembayaran (UU No 21 Tahun 2008 Bab | Pasal I ayat 8). Bank Pembiayaan Rakyat Syariah (BPRS) adalah Bank Syariah yang dalam kegiatannya tidak memberikan jasa dalam lalu lintas pembayaran (UU No 21 Tahun 2008 Bab I Pasal I ayat 9). Sedangkan Unit Usaha Syariah (UUS) adalah unit kerja dari kantor pusat Bank Umum Konvensional yang berfungsi sebagai kantor induk sebagai kantor induk dari kantor atau unit yang melaksanakan kegiatan usaha berdasarkan prinsip syariah, atau unit kerja di kantor cabang dari suatu bank yang berkedudukan di luar negeri yang melaksanakan kegiatan usaha secara konvensional yang berfungsi sebagai kantor induk dari kantor cabang pembantu syariah dan/atau unit syariah (UU No 21 Tahun 2008 Bab I Pasal I ayat 10).

\section{Prinsip Operasional Bank Syariah}

1. Prinsip Titipan (Al-Wadi'ah)

2. Prinsip Bagi Hasil (ProfitSharing)

3. Prinsip Jual-Beli (Sale and Purchase)

4. Prinsip Sewa (Operational Lease and Financial Lease)

5. Prinsip Jasa (Fee-Based Service)

Antonio (2001:83)

\section{Pembiayaan Mudharabah}

Menurut Fatwa Dewan Syariah Nasional No.07/DSN-MUI/IV/2000, pembiayaan mudharabah adalah pembiayaan yang disalurkan oleh LKS kepada pihak lain untuk usaha produktif. Menurut Antonio (2005:83) Al-Mudharabah adalah akad kejasama usaha antara dua pihak dimana pihak pertama (Shahibul Maal) menyediakan seluruh (100\%) modal, sedangakan pihak lainnya menjadi pengelola.

\section{Pembiayaan Musyarakah}

Menurut Fatwa Dewan Syariah Nasional No. 08/DSN-MUI/VI/2000 tentang pembiayaan musyarakah disebutkan bahwa pembiayaan musyarakah yaitu 
Ismah, et al/ Jurnal Ekonomi Syariah Teori dan Terapan Vol. 5 No. 3 Maret 2018: 231-246;

PENGARUH DEPOSITO MUDHARABAH, NPF DAN TINGKAT BAGI HASIL TERHADAP PEMBIAYAAN

BAGI HASIL PADA BUS DAN UUS DI INDONESIA TAHUN 2011-2016

pembiayaan berdasarkan akad

Non Performing Financing (NPF)

kerjasama antara dua pihak atau lebih

Pembiayaan bermasalah dapat untuk suatu usaha tertentu, di mana masing-masing pihak memberikan kontribusi dana dengan ketentuan bahwa keuntungan dan risiko akan ditanggung bersama sesuai dengan kesepakatan.

\section{Deposito Mudharabah}

Menurut Antonio (2001:146) dan Muhamad (2005:265) salah satu sumber dana yang bisa digunakan untuk pembiayaan adalah simpanan (DPK). Pada penelitian ini yang digunakan adalah salah satu produk dana pihak ketiga yaitu deposito mudharabah. Deposito dalam perbankan syariah menggunakan akad mudharabah karena sesuai dengan ketentuannya dan kesesuaian anatara nasabah dan bank. Menurut UU Republik Indonesia Nomor 21 Tahun 2008, dijelaskan bahwa deposito adalah investasi dana berdasarkan akad mudharabah atau lainnya yang sesuai dengan prinsip syariah yang penarikannya dapat dilakukan sesuai dengan waktu tertentu sesuai dengan akad antara bank syariah dengan nasabah.

Deposito mudah diprediksi ketersediaan dananya karena terdapat jangka waktunya, sehingga pada umumnya balas jasa yang berupa nisbah bagi hasil yang diberikan oleh bank untuk deposito lebih tinggi dibandingkan dengan tabungan mudharabah (Ismail, 2010:91). Menurut Karim (2013 : 363) mengatakan bahwa deposito syariah adalah deposito yang dijalankan berdasarkan prinsip syariah. dilihat dari tingkat Non Performing Financing (NPF). Pembiayaan bermasalah adalah pinjaman yang mengalami kesulitan pelunasan akibat adanya faktor kesengajaan dan atau karena faktor eksternal diluar kemampuan/kendali nasabah peminjam (Siamat,2005: 174). Menurut Surat Edaran BI No. 3/30/DPNP tanggal 14 Desember 2001 menyatakan bahwa Non Performing Financing (NPF) adalah suatu rasio keuangan bank yang menggambarkan besarnya tingkat pembiayaan bermasalah terhadap total pembiayaan.

\section{Tigkat Bagi Hasil}

Salah satu karakteristik bank syariah adalah adanya mekanisme bagi hasil. Bagi hasil menurut terminologi asing (inggris) dikenal dengan profit sharing. Profit sharing dalam kamus ekonomi diartikan pembagian laba. Secara definitif profit sharing diartikan : " distribusi beberapa bagian dari laba pada para pegawai dari suatu perusahaan" (Muhammad,2011 : 107).Tingkat bagi hasil adalah prosentase dalam pembagian keuntungan yang dihitung dari pendapatan setelah dikurangi beban yang berkaitan dengan pengelolaan dana (Maryanah : 2005).

\section{Hubungan Antar Variabel}

1. Pertumbuhan perbankan syariah tidak hanya dilihat dari pertumbuhan aset yang meningkat setiap tahunnya, tetapi juga dari jumlah dana pihak ketiga yang dapat dihimpun dari masyarakat oleh bank 
Ismah, et al/ Jurnal Ekonomi Syariah Teori dan Terapan Vol. 5 No. 3 Maret 2018: 231-246;

PENGARUH DEPOSITO MUDHARABAH, NPF DAN TINGKAT BAGI HASIL TERHADAP PEMBIAYAAN BAGI HASIL PADA BUS DAN UUS DI INDONESIA TAHUN 2011-2016

syariah. Menurut Antonio (2001:146) dan

Muhamad (2005:265) salah satu sumber dana yang bisa digunakan untuk pembiayaan adalah simpanan (DPK). Pada penelitian ini, sumber dana yang dihasilkan oleh bank umum syariah yang digunakan peneliti untuk menjelaskan pembiayaan bagi hasil adalah deposito mudharabah. Menurut Ismail (2010 : 91) deposito mudah diprediksi ketersediaan dananya karena terrdapat jangka waktu dalam penempatannya. Sifat deposito yaitu penarikannya hanya dapat dilakukan sesuai jangka waktunya, sehingga pada umumnya balas jasa yang berupa nisbah bagi hasil yang diberikan oleh bank untuk deposito lebih tinggi dibandingkan dengan tabungan mudharabah. Semakin tinggi deposito mudharabah yang dapat dihimpun oleh bank syariah maka akan meningkatkan jumlah pembiayaan bagi hasil yang akan disalurkan oleh bank syariah. Hubungan antara Deposito Mudharabah terhadap pembiayaan bagi hasil yang telah dilakukan pada penelitian sebelumnya oleh Yulianto dan Asrori (2015) dan Maryanah (2006)menunjukkan bahwa variabel dana pihak ketiga berpengaruh positif dan signifikan terhadap pembiayaan berbasis bagi hasil.

2. Kegiatan pembiayaan yang dilakukan oleh perbankan syariah tidak dapat lepas dengan risiko, salah satu risiko pembiayaan adalah terjadinya pembiayaan bermasalah. Pembiayaan bermasalah dapat dilihat dari tingkat Non Performing Financing (NPF). Menurut Surat
Edaran BI No. 3/30/DPNP tanggal 14

Desember 2001 menyatakan bahwa Non Performing Financing (NPF) adalah suatu rasio keuangan bank yang menggambarkan besarnya tingkatpembiayaan bermasalah terhadap total pembiayaan. Tingginya tingkat NPF akan berdampak negative bagi pihak bank, karena NPF berpengaruh terhadap jumlah PPAP yang jika terus-menerus meningkat akan berakibat pada mengurangnya jumlah modal. Hubungan antara NPF terhadap pembiayaan bagi hasil yang telah dilakukan pada penelitian sebelumnya oleh Prasasti (2014) dan Annisa dan Rizal (2015) menunjukkan bahwa variabel non performing financing berpengaruh negatif signifikan terhadap jumlah pembiayaan bagi hasil.

3.Bagi hasil adalah sistem pembagian hasil utama dimana pemilik modal bekerjasama dengan pemilik modal untuk melakukan kegiatan usaha. Apabila kegiatan usaha menghasilkan keuntungan maka dibagi berdua dan ketika mengalami kerugian ditanggung bersama pula. Sistem bagi hasil menjamin adanya keadilan dan tidak ada pihak yang tereksploitasi (Ascarya, 2006: 26). Tingkat bagi hasil pembiayaan adalah salah satu faktor penting dalam menentukan besarnya pembiayaan berbasis bagi hasil. Semakin tinggi tingkat bagi hasil dibandingkan risiko yang harus di tanggung maka akan menarik nasabah lebih banyak dan membuat bank syariah akan meningkatkan jumlah pembiayaan 
Ismah, et al/ Jurnal Ekonomi Syariah Teori dan Terapan Vol. 5 No. 3 Maret 2018: 231-246;

PENGARUH DEPOSITO MUDHARABAH, NPF DAN TINGKAT BAGI HASIL TERHADAP PEMBIAYAAN BAGI HASIL PADA BUS DAN UUS DI INDONESIA TAHUN 2011-2016

bagi hasil. Hubungan antara Tingkat Bagi

Hasil terhadap pembiayaan bagi hasil yang telah dilakukan pada penelitian sebelumnya Andraeny (2011) dan Annisa dan Rizal (2015) variabel tingkat bagi hasil berpengaruh positif signifikan terhadap pembiayaan berbasis bagi hasil.

\section{Hipotesis}

Berdasarkan teori dan konsep yang dijelaskan dalam rumusan masalah, tujuan, dan landasan teori penelitian ini, maka hipotesis dalam penelitian ini dapat dirumuskan sebagai berikut :

Hipotesis 1:Variabel DepositoMudharabah, NPF dan tingkat bagi hasil secara simultan berpengaruh signifikan terhadap pembiayaan bagi hasil pada BUS dan UUS di Indonesia.

Hipotesis 2:Variabel Deposito Mudharabah secara parsialberpengaruh signifikan terhadap pembiayaan bagi hasil pada BUS dan UUS di Indonesia.

Hipotesis 3:Variabel NPF secaraparsial berpengaruh signifikan terhadap pembiayaan bagi hasil pada BUS dan UUS di Indonesia.

Hipotesis 4:Variabel tingkat bagi hasil secara parsial berpengaruh signifikan terhadap pembiayaan bagi hasil pada BUS dan UUS di Indonesia.

\section{Model Analisis}

Model analisis dalam penelitian ini dapat digambarkan sebagai berikut :

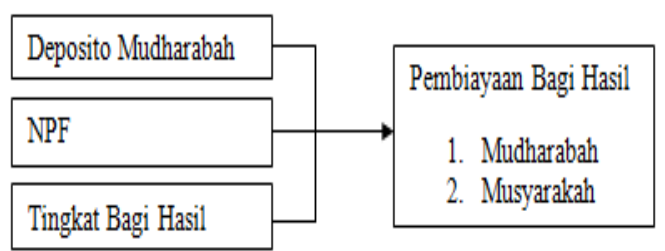

Sumber : Data diolah Gambar 1.

Pengaruh Simultan dan Parsial Deposito Mudharabah, Non Performing Financing dan Tingkat Bagi Hasil Terhadap Pembiayaan Bagi Hasil

\section{METODE PENELITIAN}

\section{Pendekatan Penelitian}

Pendekatan penelitian yang digunakan dalam penenlitian ini adalah pendekatan kuantitatif. Metode penelitian kuntitatif dapat diartikan sebagai metode dapat diartikan sebagai metode penelitian yang berlandaskan pada filsafat positivisme, digunakan untuk meneliti pada populasi atau sampel tertentu, pengumpulan data menggunakan instrument penelitian, analisis data bersifat kuantitatif/statistic, dengan tujuan untuk menguji hipotesis yang telah ditetapkan (Sugiyono 2012:8). Program statistic yang digunakan dalam pengolahan data menggunakan program SPSS versi 16,0.

\section{Identifikasi Variabel}

Variabel yang digunakan dalam penelitian ini terdiri dari dua jenis, yaitu variabel independen dan variabel dependen. Variabel independen adalah variabel bebas yang mempengaruhi variabel terikat. Variabel independen dalam penelitian ini adalah Deposito Mudharabah, Non Performing Financing 
Ismah, et al/ Jurnal Ekonomi Syariah Teori dan Terapan Vol. 5 No. 3 Maret 2018: 231-246;

PENGARUH DEPOSITO MUDHARABAH, NPF DAN TINGKAT BAGI HASIL TERHADAP PEMBIAYAAN BAGI HASIL PADA BUS DAN UUS DI INDONESIA TAHUN 2011-2016

Tingkat Bagi Hasil.Variabel dependen

variabel terikat yang perubahannya dipengaruhi oleh variabel bebas. Variabel dependen dalam penelitian ini adalah Pembiayaan Bagi Hasil (Mudharabah dan Musyarakah)

\section{Definisi Operasional Variabel}

1. Deposito Mudharabah

$$
\text { Deposito }
$$

mudharabah, yaitu investasi melalui simpanan pihak ketiga (perseorangan atau badan hukum) yang penarikannya hanya dapat dilakukan dalam jangka waktu tertentu dengan mendapat imbalan bagi hasil (Antonio,2001). Nilai total deposito mudharabah yang diperoleh dari Statistik Perbankan Syariah BUS dan UUS bulanan mulai bulan Januari 2011 hingga bulan Agustus 2016. Menurut Yulianto dan Asrori (2015) deposito mudharabah diukur dengan menggunakan rumus :

Deposito Mudharabah $=$ Total Deposito Mudharabah yang dihimpun dari dalam negeri + luar negeri

2. NPF

Kegiatan pembiayaan yang dilakukan oleh perbankan syariah tidak dapat lepas dengan risiko, salah satu risiko pembiayaan adalah terjadinya pembiayaan bermasalah. Pembiayaan bermasalah dapat dilihat dari tingkat Non Performing Financing(NPF). Nilai Non Performing
Financing diperoleh dari Statistik Perbankan Syariah (BUS) dan Unit Usaha Syariah (UUS) bulanan mulai Januari 2011 sampai dengan Agustus 2016 yang dirumuskan sebagai berikut :Total Pembiayaan Bermasalah $\times 100 \%$ Total Pembiayaan

3. Tingkat Bagi Hasil

Tingkat bagi hasil (equivalen rate), adalah rata-rata tingkat imbalan yang diterima bank syariah atas pembiayaan bagi hasil pada waktu tertentu (Andraeny, 2011). Nilai Tingkat Bagi Hasil diperoleh dari laporan bulanan Ekuivalen Tingkat Imbalan/Bagi Hasil Bank Umum Syariah dan Unit Usaha Syariah dari Statistik Perbankan Syariah periode mulai bulan Januari 2011 sampai dengan bulan Agustus 2016. Menurut Yulianto dan Asrori (2015) deposito mudharabah diukur dengan menggunakan rumus:

Bagi Hasil yang Diterima $\times 100 \%$

Total Pembiayaan yang Disalurkan

4. Pembiayaan Bagi Hasil

Pembiayaan berbasis bagi hasil atau sering disebut juga dengan Natural Uncertainty Contracts merupakan kontrak yang tidak memberikan kepastian return. Yang termasuk dalam kontrak ini adalah pembiayaan yang bersifat investasi yaitu pembiayaan mudharabah dan pembiayaan musyarakah. Nilai 
Ismah, et al/ Jurnal Ekonomi Syariah Teori dan Terapan Vol. 5 No. 3 Maret 2018: 231-246;

PENGARUH DEPOSITO MUDHARABAH, NPF DAN TINGKAT BAGI HASIL TERHADAP PEMBIAYAAN BAGI HASIL PADA BUS DAN UUS DI INDONESIA TAHUN 2011-2016

Pembiayaan Mudharabah dan Musyarakah diperoleh dari Statistik Perbankan Syariah (BUS) dan Unit Usaha Syariah (UUS) bulanan mulai Januari 2011 sampai dengan Agustus 2016. Menurut Yulianto dan Asrori (2015) deposito mudharabah diukur dengan menggunakan rumus :

Pembiayaan Bagi Hasil $=$ Total Pembiayaan Mudharabah + Musyarakah yang disalurkan.

\section{Jenis dan Sumber Data}

Jenis data yang digunakan dalam penelitian ini merupakan data yang bersifak sekunder yang merupakan data time series dari bulan Januari 2011 sampai dengan Bulan Agustus 2016. Sumber dana yang digunakan dalam penelitian ini diperoleh dari Statistik Perbankan Syariah (BUS) dan Unit Usaha Syariah (UUS) yang diterbitkan oleh Otoritas Jasa Kevangan melalui situs resmi OJK www.ojk.go.id.

\section{Teknik Analisis}

Teknik analisis yang digunakan adalah regresi linier berganda dengan menggunakan metode kuadrat kecil biasa (Ordinary Least Square atau OLS).

\section{HASIL DAN PEMBAHASAN}

\section{Uji Normalitas}

Uji Normalitas untuk menguji apakah residual data dari regresi linear ini memiliki distribusi normal atau tidak. Salah satu metode yang digunakan untuk melakukan uji normalitas adalah dengan menggunakan metode probability plot. Apabila data menyebar disekitar garis diagonal dan mengikuti arah garis, maka model regresi memenuhi uji asumsi normalitas.

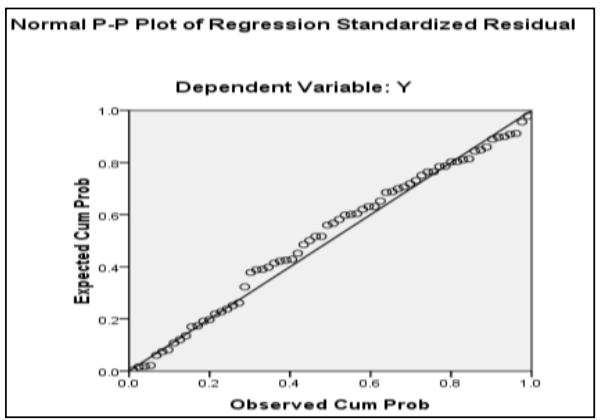

Sumber : Hasil Olah Data di SPSS Gambar 2 GrafikP-P Plot Hasil Uji

Tabel 1

Tabel Kolmogrov Hasil Uji Normalitas

One-Sample Kolmogorov-Smirnov Test

\begin{tabular}{|c|c|c|}
\hline & & $\begin{array}{l}\text { Unstandardized } \\
\text { Residual }\end{array}$ \\
\hline$N$ & & 68 \\
\hline Normal Param & Mean & ,0000000 \\
\hline & $\begin{array}{l}\text { Std, } \\
\text { Deviation }\end{array}$ & $1,95257125 \mathrm{E} 3$ \\
\hline Most Extreme & Absolute & ,081 \\
\hline 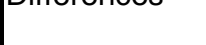 & Positive & ,054 \\
\hline & Negative & -.081 \\
\hline Kolmogorov-S & & 672 \\
\hline Asymp. Sig. (2 & & ,758 \\
\hline
\end{tabular}

Sumber : Hasil Olah Data di SPSS

Pada gambar 3 data menyebar disekitar garis diagonal, maka dapat dikatakan model memenuhi asumsi normalitas. Pada tabel 1 nilai kolmogrov adalah 0,578 pada signifikansi 0,892 karena signifikansi di atas 0,05 maka data tersebut terdistribusi normal.

\section{Uji Mulltikolinearitas}

Uji Multikolinearitas digunakan untuk mengetahui adanya korelasi atau hubungan antar masing- masing variabel dalam penelitian ini. Cara mengetahui 
Ismah, et al/ Jurnal Ekonomi Syariah Teori dan Terapan Vol. 5 No. 3 Maret 2018: 231-246;

PENGARUH DEPOSITO MUDHARABAH, NPF DAN TINGKAT BAGI HASIL TERHADAP PEMBIAYAAN BAGI HASIL PADA BUS DAN UUS DI INDONESIA TAHUN 2011-2016

masing- masing variabel independen yang diteliti dari multikolinearitas dapat diukur dari VIF (Variance Inflation Factor) dan tolerance value. Batasan yang digunakan untuk mengetahui bebas multikolinearitas adalah VIF kurang dari 10 dan tolerance value lebih dari 0,1.

Tabel 2

Hasil Uji Multikolinearitas

\begin{tabular}{|l|l|c|}
\hline \multicolumn{1}{|c|}{ Variabel Bebas } & Tolerance & VIF \\
\hline $\begin{array}{l}\text { Deposito } \\
\text { Mudharabah }\end{array}$ & 0,401 & 2,494 \\
\hline NPF & 0,438 & 2,284 \\
\hline Tingkat Bagi Hasil & 0,850 & 1,777 \\
\hline
\end{tabular}

Sumber : Hasil Olah Data di SPSS

Hasil uji multkolinearitas pada tabel

2 menunjukan bahwa semua variabel bebas mempunyai nilai tolerance lebih besar dari 0,10 dan nlai VIF < 10. Dapat disimpulkan bahwa tidak terjadi multikolinearitas.

\section{Uji Heteroskedastisitas}

Uji Heteroskedastisitas untuk menguji apakah dalam model regresi ini terjadi ketidaksamaan varians dari residual satu pengamatan ke pengamatan yang lain. Cara mendeteksi problem heteroskedastisitas dapat dilakukan dengan melihat grafik scatterplot apabila titik- titik pada scatterplot tidak berpola atau menyebar maka tidak terjadi heteroskedastisitas.

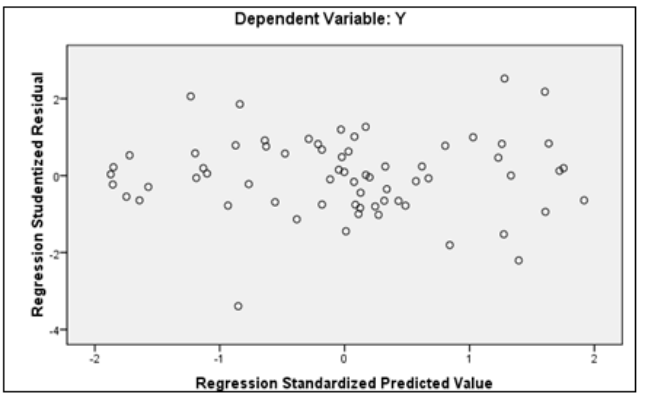

Sumber : Hasil Olah Data di SPSS

\section{Gambar 3}

Hasil Uji Heteroskedastisitas

Pada gambar 3 di atas menunjukkan bahwa titik- titik tidak berpola dan menyebar secara acak sehingga tidak terjadi masalah heteroskedastisitas dalam model regresi penelitian ini.

\section{Uji Autokorelasi}

Uji Autokorelasi untuk menguji adanya korelasi antara variabel gangguan satu observasi dengan gangguan variabel observasi lain. Salah satu metode yang digunakan untuk pengujian autokorelasi adalah dengan menggunakan metode Durbin Watson. Pengujian autokorelasi ini menggunakan nilai DW (Durbin Watson) yaitu apabila nilai DW diantara -2 dan +2 maka tidak terjadi masalah autokorelasi.

Tabel 3

Model Summaryb

\begin{tabular}{|c|c|c|c|c|c|}
\hline Model & $R$ & $\begin{array}{c}\mathrm{R} \\
\text { Square }\end{array}$ & $\begin{array}{c}\text { Adjusted } \\
R \\
\text { Square }\end{array}$ & $\begin{array}{l}\text { Std. Error } \\
\text { of the } \\
\text { Estimate }\end{array}$ & $\begin{array}{l}\text { Durbin- } \\
\text { Watson }\end{array}$ \\
\hline 1 & $0,994 a$ & 0,988 & 0,987 & 1997,81057 & 0,560 \\
\hline
\end{tabular}

Hasil uji Autokorelasi

Sumber : Hasil Olah Data di SPSS 
Ismah, et al/ Jurnal Ekonomi Syariah Teori dan Terapan Vol. 5 No. 3 Maret 2018: 231-246;

PENGARUH DEPOSITO MUDHARABAH, NPF DAN TINGKAT BAGI HASIL TERHADAP PEMBIAYAAN BAGI HASIL PADA BUS DAN UUS DI INDONESIA TAHUN 2011-2016

Pada tabel 3 di atas menunjukkan

bahwa tidak terdapat masalah autokorelasi pada model regresi yang digunakan dalam penelitian ini karena nilai DW berada diantara -2 dan +2 .

\section{Analisis Regresi Linear Berganda}

Berdasarkan hasil pengujian yang telah dilakukan didapat persamaan regrresi linear berganda sebagai berikut:

$\mathrm{PBH}=7381,516+0,478 \mathrm{DM}-1739,475 \mathrm{NPF}$ $+242,211 \mathrm{TBH}$.

Dimana :

PBH $=$ Pembiayaan Bagi hasil

DM = Deposito Mudharabah

NPF $=$ Non Performing Financing

$\mathrm{TBH}=$ Tingkat Bagi Hasil

Berdasarkan persamaan diatas, maka dapat dijelaskan sebagai berikut:

1. Konstanta sebesar 7381,516 menunjukan apabila Deposito Mudharabah, NPF dan Tingkat Bagi Hasil besarnya nol atau constant, maka nilai Pembiayaan Bagi Hasil sebesar 7.381.516.000.000.

2. Nilai koefesien regresi variabel Deposito Mudharabah sebesar 0,478 menunjukan bahwa setiap kenaikan satu persen variabel Deposito Mudharabah akan menaikkan variabel Pembiayaan Bagi Hasil sebesar 478.000 .000 dengan asumsi variabel lain tetap.

3. Nilai koefesien regresi variabel Non Performing Financing sebesar 1739,475 menunjukan bahwa

setiap kenaikan satu persen variabel NPF akan menurunkan variabel Pembiayaan Bagi Hasil sebesar 1.739.475.000.000 dengan asumsi variabel lain tetap.

4. Nilai koefesien regresi variabel Tingkat Bagi Hasil sebesar 242,211 menunjukan bahwa setiap kenaikan satu persen variabel Tingkat Bagi Hasil akan menaikkan variabel Pembiayaan Bagi Hasil sebesar 242.211.000.000 dengan asumsi variabel lain tetap.

\section{Pengujian Hipotesis}

Tabel 4

Pengaruh Deposito Mudharabah, NPF dan Tingkat Bagi Hasil terhadap Jumlah Pembiayaan Mudharabah dan Musyarakah secara simultan.

\begin{tabular}{|c|c|c|c|c|c|}
\hline Model & $\begin{array}{l}\text { Sum of } \\
\text { Squares }\end{array}$ & df & $\begin{array}{l}\text { Mean } \\
\text { Square }\end{array}$ & $\mathrm{F}$ & Sig. \\
\hline $\begin{array}{ll}1 & \text { Regressi } \\
\text { on }\end{array}$ & 6810,172 & 4 & 1702,543 & $1,725 \mathrm{E} 3$ & $0,000^{\circ}$ \\
\hline Residual & 446,542 & 62 & 7,202 & & \\
\hline Total & 7256,715 & 66 & & & \\
\hline
\end{tabular}

Sumber : Hasil Olah Data di SPSS

Hasil uji F (simultan) pada tabel 4menunjukkan bahwa pengaruh Deposito Mudharabah, NPF dan Tingkat Bagi Hasil sebesar 236,389 dengan tingkat signifikansi 0,000 . Nilai signifikansi tersebut lebih kecil dari 0,05 sehingga dapat disimpulkan bahwa variabel Deposito Mudharabah, NPF dan Tingkat Bagi Hasil secara simultan berpengaruh signifikan terhadap Pembiayaan Bagi Hasil 
Ismah, et al/ Jurnal Ekonomi Syariah Teori dan Terapan Vol. 5 No. 3 Maret 2018: 231-246;

PENGARUH DEPOSITO MUDHARABAH, NPF DAN TINGKAT BAGI HASIL TERHADAP PEMBIAYAAN BAGI HASIL PADA BUS DAN UUS DI INDONESIA TAHUN 2011-2016

Tabel 5

Pengaruh Deposito Mudharabah, NPF dan Tingkat Bagi Hasil terhadap Jumlah

Pembiayaan Mudharabah dan Musyarakah secara simultan.

\begin{tabular}{|c|c|c|c|c|c|}
\hline \multirow{2}{*}{ Model } & \multicolumn{2}{|c|}{$\begin{array}{c}\text { Unstandardized } \\
\text { Coefficients }\end{array}$} & \multirow{2}{*}{\begin{tabular}{|c|}
$\begin{array}{c}\text { Standardized } \\
\text { Coefficients }\end{array}$ \\
Beta \\
\end{tabular}} & \multirow{2}{*}{$\dagger$} & \multirow{2}{*}{ Sig. } \\
\hline & B & $\begin{array}{l}\text { Std. } \\
\text { Error }\end{array}$ & & & \\
\hline (Constant) & $7381,516 \mid$ & $902,450 \mid$ & & 8,179 & ,000 \\
\hline $\begin{array}{l}\text { Deposito } \\
\text { Mudharabah } \\
\text { (miliar) }\end{array}$ & ,478 & ,012 & ,881 & 40,383. & .000 \\
\hline $\begin{array}{c}\text { Non } \\
\text { Performing } \\
\text { Financing } \\
(\%)\end{array}$ & 1739,475 & 321,719 & .113 & $-5,407$ & .000 \\
\hline $\begin{array}{l}\text { Tingkat Bagi } \\
\text { Hasil (\%) }\end{array}$ & 242,211 & 58,421 & .062 & 4,146 & .000 \\
\hline
\end{tabular}

Sumber : Hasil Olah Data di SPSS

Hasil uji $\dagger$ (parsial) menunjukkan bahwa pengaruh Deposito Mudharabah memiliki nilai signifikansi sebesar 0,000,NPF memiliki nilai signifikansi sebesar 0,000, dan Tingkat Bagi Hasil memiliki nilai signifikansi sebesa 0,000 .

Variabel yang memiliki nilai signifikansi t-statistik lebih kecil dari 0,05 adalah variabel NPF. Sehingga dapat disimpulkan bahwa variabel Deposito Mudharabah dan Tingkat Bagi Hasil berpengaruh positif signifikan NPF secara parsial berpengaruh negatif signifikan terhadap Pembiayaan Bagi Hasil.

PembahasanPengaruh

Deposito

Mudharabah, NPF dan Tingkat Bagi Hasil terhadap Jumlah Pembiayaan

Mudharabah dan Musyarakah pada BUS dan UUS di Indonesia tahun 2011-2016

1. Berdasarkan pengujian secara simultan menunjukkan bahwa nilai $F$ sebesar 1,725 dengan tingkat signifikansi 0,000, sehingga dapat disimpulkan bahwa Deposito Mudharabah,NPF dan Tingkat Bagi Hasil berpengaruh signifikan terhadap Pembiayaan Bagi Hasil. Hal ini dikarenakan dalam menyalurkan pembiayaan bagi hasil bank perlu memperhatikan aspek lain, tidak hanya aspek penghimpunan dana melalui deposito mudharabah saja melainkan perlu memperhatikan tingkat bagi hasil serta NPF yang bisa mngurangi modal yang dimiliki bank.

2. Berdasarkan pengujian secara parsial menunjukkan bahwa nilai t-statistik sebesar 40,383 dengan tingkat signifikansi 0,000 , sehingga dapat disimpulkan bahwa variabel Deposito Mudharabah berpengaruh signifikan terhadap Pembiayaan Bagi Hasil. Menurut Antonio (2001: 146) dan Muhammad (2005: 265) salah satu sumber dana yang bisa digunakan untuk pembiayaan adalah simpanan (DPK). Dana pihak ketiga merupakan sumber utama pembiayaan yang akan disalurkan oleh perbankan syariah. Salah satu dana pihak ketiga yang digunakan dalam penelitian ini adalah deposito mudharabah. Menurut UU Republik Indonesia Nomor 21 Tahun 2008, dijelaskan bahwa deposito adalah investasi dana berdasarkan akad mudharabah atau lainnya yang sesuai dengan prinsip syariah yang penarikannya dapat dilakukan sesuai dengan waktu 
Ismah, et al/ Jurnal Ekonomi Syariah Teori dan Terapan Vol. 5 No. 3 Maret 2018: 231-246;

PENGARUH DEPOSITO MUDHARABAH, NPF DAN TINGKAT BAGI HASIL TERHADAP PEMBIAYAAN BAGI HASIL PADA BUS DAN UUS DI INDONESIA TAHUN 2011-2016

tertentu sesuai dengan akad antara bank syariah dengan nasabah.

Secara teori meningkatnya deposito mudharabah berpengaruh terhadap peningkatan jumlah pembiayaan bagi hasil yang disalurkan oleh BUS dan UUS. Semakin banyak dana yang dapat dihimpun oleh perbankan syariah, maka akan semakin tinggi pula pembiayaan yang dapat disalurkan oleh BUS dan UUS. Menurut Andraeny (2011) pembiayaan bagi hasil dapat membantu mendorong perkembangaan sector riil di Indonesia dibandingkan pembiayaan non bagi hasil. Oleh karena itu, semakin besar volume pembiayaan bagi hasil yang disalurkan bank syariah kepada masyarakat semakin besar pula kontribusi yang diberikan bank syariah terhadap perekonomian Indonesia.

3. Berdasarkan pengujian secara parsial menunjukkan bahwa nilai t-statistik sebesar $-5,407$ dengan tingkat signifikansi 0,000 , sehingga dapat disimpulkan bahwa variabel NPF berpengaruh negatif signifikan terhadap Pembiayaan Bagi Hasil. Meningkatnya NPF akan berdampak pada menurunnya jumlah modal yang dimiliki oleh bank. NPF yang terus menerus mengalami peningkatan akan berdampak buruk pada BUS dan UUS karena BUS dan UUS akan kehilangan kesempatan dalam memperoleh laba dari pembiayaan yang disalurkan sehingga akan mengurangi perolehan laba. Menurunnya jumlah modal akan berakibat pada rendahnya jumlah dana pembiayaan bagi hasil yang akan disalurkan.

Berdasarkan pengujian secara parsial menunjukkan bahwa nilai t-statistik sebesar 4,146 dengan tingkat signifikansi 0,000 , sehingga dapat disimpulkan bahwa variabel Tingkat Bagi Hasil berpengaruh tetapi signifikan terhadap Pembiayaan Bagi Hasil. Bagi hasil adalah salah satu prinsip yang penting bagi produk mudharabah dan musyarakah yang terdapat pada landasan operasional perbankan syariah. Menurut Fatwa DSN MUI Nomor 15/DSN-MUI/IX/2000 tentang prinsip distribusi hasil usaha dalam lembaga keuangan syariah, pembagian hasil usaha di antara para pihak (mitra) dalam suatu bentuk usaha kerjasama boleh didasarkan pada prinsip bagi untung (profit sharing), yakni bagi hasil yang dihitung dari pendapatan setelah dikurangi modal dan biaya-biaya dan boleh pula didasarkan pada prinsip bagi hasil (net revenue sharing), yakni bagi hasil yang dihitung dari pendapatan setelah dikurangi modal. Menurut Andraeny (2011) tingkat bagi hasil (equivalen rate), adalah rata-rata tingkat imbalan yang diterima bank syariah atas pembiayaan bagi hasil pada waktu tertentu.

Secara teori meningkatnya tingkat bagi hasil yang diperoleh perbankan syariah akan berdampak kepada meningkatnya jumlah pendapatan BUS 
Ismah, et al/ Jurnal Ekonomi Syariah Teori dan Terapan Vol. 5 No. 3 Maret 2018: 231-246;

PENGARUH DEPOSITO MUDHARABAH, NPF DAN TINGKAT BAGI HASIL TERHADAP PEMBIAYAAN BAGI HASIL PADA BUS DAN UUS DI INDONESIA TAHUN 2011-2016

dan UUS. Tingkat bagi hasil yang tinggi

menyebabkan pendapatan yang

diterima oleh BUS dan UUS juga

meningkat, dengan meningkatnya jumlah pendapatan maka akan semakin tinggi pula pembiayaan yang dapat disalurkan oleh BUS dan UUS.

\section{SIMPULAN}

Berdasarkan pembahasan hasil penelitian dan juga pembahsan yang telah dilakukan mengenai Pengaruh Deposito Mudharabah, Non Performing Financing dan Tingkat Bagi Hasil terhadap Pembiayaan Bagi Hasil pada BUS dan UUS di Indonesia tahun 20112016 maka simpulan yang dapat diambil adalah:

1. Berdasarkan hasil statistik uji F, menunjukkan nilai signifikansi lebih kecil dari a $(0,000<0,05)$, sehingga dapat disimpulkan bahwa Deposito Mudharabah, Non Performing Financing, dan Tingkat Bagi Hasil secara simultan berpengaruh signifikan terhadap Pembiayaan Berbasis Bagi Hasil pada Industri Perbankan Syariah di Indonesia periode 2011-2016.

2. Berdasarkan hasil statistik uji t, menunjukkan bahwa nilai signifikansi Deposito Mudharabah lebih kecil dari a $(0,000<0,05)$ sehingga dapat disimpulkan bahwa Deposito Mudharabah secara parsial berpengaruh signifikan terhadap Pembiayaan Berbasis
Bagi Hasil pada Industri Perbankan Syariah di Indonesia periode 2011-2016.

3. Berdasarkan hasil statistik uji t, menunjukkan bahwa nilai signifikansi Non Performing Financing (NPF) lebih kecil dari a $(0,000<0,05)$ sehingga dapat disimpulkan bahwa Non Performing Financing (NPF) secara parsial berpengaruh signifikan terhadap Pembiayaan Berbasis Bagi Hasil pada Industri Perbankan Syariah di Indonesia periode 2011-2016.

4. Berdasarkan hasil statistik uji t, menunjukkan bahwa nilai signifikansi Tingkat Bagi Hasil lebih kecil dari a $(0,000<0,05)$ sehingga dapat disimpulkan bahwa Tingkat Bagi Hasil secara parsial berpengaruh signifikan terhadap Pembiayaan Berbasis Bagi Hasil pada Industri Perbankan Syariah di Indonesia periode 2011-2016.

\section{DAFTAR PUSTAKA}

Al-Qur'an dan Terjemahannya.

Andraeny, Dita. 2011. "Analisis Pengaruh Dana Pihak Ketiga, Tingkat Bagi Hasil, dan Non Performing Financing terhadap Volume Pembiayaan Berbasis Bagi Hasil pada Perbankan Syariah di Indonesia." Simposium Nasional Akuntansi XIV 47. Fakultas Ekonomi Universitas Syiah Kuala Banda Aceh. 
Ismah, et al/ Jurnal Ekonomi Syariah Teori dan Terapan Vol. 5 No. 3 Maret 2018: 231-246;

PENGARUH DEPOSITO MUDHARABAH, NPF DAN TINGKAT BAGI HASIL TERHADAP PEMBIAYAAN BAGI HASIL PADA BUS DAN UUS DI INDONESIA TAHUN 2011-2016

Annisa, Lintang Nurul dan Rizal Yaya. 2015.

Tesis.

Jakarta : Universitas

"Pengaruh Dana Pihak Ketiga, Indonesia.

Tingkat Bagi Hasil dan Non

Performing Financing Terhadap

Volume dan Porsi Pembiayaan

Berbasis Bagi Hasil pada

Perbankan Syariah di Indonesia".

Share Vol. 4. No. 1. Fakultas

Ekonomi Universitas Muhamadiyah Malang.

Antonio, Muhammad Syafi'i. 2001. Bank

Syariah dari Teori ke Praktek.

Jakarta : Gema Insani Press.

Ascarya. 2006. Akad dan Produk Bank

Syariah. Jakarta: PT Raja Grafindo.

Ascarya dan Diana, Yumanita. 2005.

Mencari Solusi Rendahnya
Pembiayaan Bagi Hasil di
Perbankan Syariah Indonesia.
Jakarta: Bank Indonesia.

Fatwa Dewan Syariah Nasional No.07/

DSN- MUI/VI/2000 tentang Mudharabah.

Fatwa Dewan Syariah Nasional No.08/

DSN- MUI/VI/2000 tentang Musyarakah.

Nurhasanah, Neneng. 2010. "Optimalisasi

Peran Mudharabah Sebagai Salah

Satu Akad Kerjasama Dalam

Pengembangan Ekonomi Syariah".

Syiar Hukum Vol.XII. No.3

November 2010. Hal 285-296.

Fakultas Syariah Universitas Islam Bandung.

Maryanah. 2006. "Analisis Faktor- Faktor yang Mempengaruhi Pembiayaan Bagi Hasil di Bank Syariah Mandiri".

Muhammad. 2005. Sistem dan Prosedur Operasional

Bank

Syariah.Yogyakarta: UII Press.

2011. Manajemen Bank Syariah. Yogyakarta: UII Press.

Nurhasanah, Neneng. 2010. "Optimalisasi Peran Mudharabah Sebagai Salah Satu Akad Kerjasama Dalam Pengembangan Ekonomi Syariah". Syiar Hukum Vol.XII. No.3 November 2010. Hal 285-296. Fakultas Syariah Universitas Islam Bandung.

Otoritas Jasa Keuangan. 2010. Statistik Perbankan Syariah. (Online), (http://www.ojk.go.id, di akses 20 September 2016).

2011. Statistik

Perbankan Syariah. (Online), (http://www.ojk.go.id, di akses 20 September 2016).

2012. Statistik Perbankan Syariah. (Online), (http://www.ojk.go.id, di akses 20 September 2016).

2013. Statistik

Perbankan Syariah. (Online), (http://www.ojk.go.id, di akses 20 September 2016).

2014. Statistik

Perbankan Syariah. (Online), (http://www.ojk.go.id, di akses 20 September 2016). 
2015. Statistik

Perbankan Syariah. (Online),

(http://www.ojk.go.id, di akses 20 September 2016).

2016. Statistik

Perbankan Syariah. (Online), (http://www.ojk.go.id, di akses 20 September 2016).

Siamat, Dahlan. 2005. Manajemen Lembaga Keuangan. Jakarta: Lembaga Penerbit Fakultas Ekonomi Universitas Indonesia.

Sugiyono. 2012. Metode Penelitian Bisnis (Pendekatan Kuantitatif, Kualitatif dan R\&D). Jakarta: Alfabeta.

Surat Edaran Bank Indonesia No. 3/30/DPNP tanggal 14 Desember 2001.

Susanti, Vera. 2015. "Pengaruh Equivalent Rate dan Tingkat Keuntungan Terhadap Dana Pihak Ketiga (DPK) Perbankan Syariah di Indonesia." IFinance: a Research Journal on Islamic Finance Vol.l No.l. Universitas Islam Negeri Raden Fatah Palembang.

Undang- Undang Republik Indonesia Nomor 21 Tahun 2008 Bab I Pasal I ayat 7, 8, 9 Tentang Bank Syariah .

Yulianto, Agung dan Asrori. 2015. Analisis Faktor Internal Perbankan Syariah Dalam Upaya Optimalisasi Pembiayaan Bagi Hasil. Fakultas Ekonomi Universitas Negeri Semarang diunduh dari www.multiparadigma.lecture.ub.a<smiles>C=[GeH2]</smiles> 